\title{
AKTIVITAS ANTIFUNGI TEMU PUTIH (Curcuma zedoaria) TERHADAP Trichophyton mentagrophytes
}

\author{
Siska Nuryanti \\ Fakultas Farmasi Universitas Muslim Indonesia, Makassar \\ Email : siska.nuryanti@umi.ac.id
}

\begin{abstract}
Curcuma zedoaria has long been known to be used in treatment of dermatophytosis; a skin disease caused by dermatophytes fungi such as Trichophyton mentagrophytes. The fungi infects hairs, skins, and nails that contain keratin. The study was conducted in order to measure the effect of ethanol extract of curcuma zedoaria in inhibiting Trichophyton mentagrohytes colonies. Results showed that the curcuma zedoaria ekstract inhibited Trichophyton mentagrophytes. The research was continued by Minimum Inhibitory Concentration (MIC) test by liquid dilution method in Sabaroud Dekstrosa Broth. Ethanol extract curcuma zedoaria did not indicate the value of the MIC test because due to the color and viscosity of samples which interfere with the observations. As for the positive control shows a clear color, that indicating the presence of inhibitory Trichophyton mentagrophytes by ketokonazol. For the value of the Minimum Fungicidal Concentration (MFC) to Trichophyton mentagrophytes are present in a concentration of $50 \%$.
\end{abstract}

Keyword :Trichophyton mentagrophytes, Curcuma zedoaria, MIC, MFC.

PENDAHULUAN

Dermatofita

merupakan

kelompok jamur yang memiliki kemampuan untuk melekat pada keratin dan menggunakannya sebagai sumber nutrisi yang memungkinkan jamur tersebut untuk berkoloni pada jaringan yang mengandung keratin, seperti stratum korneum epidermis, rambut dan kuku. Penyakit ini dapat menyerang semua umur tetapi lebih sering menyerang anak-anak. ${ }^{1}$
Dermatofit merupakan jamur yang sangat khusus dan penyebab palling umum dari superficial mycoses. Penyebab infeksi dermatofita yang paling dominan adalah Tricophyton diikuti Epidermophyton dan Microsporum, dimana yang paling banyak adalah spesies Tricophyton rubrum diikuti T.mentagrophytes, $M$. canis dan T.tonsurans. ${ }^{2}$

Antifungi merupakan salah satu antibiotika yang digunakan untuk 
menyembuhkan infeksi yang disebabkan oleh fungi atau jamur. Antifungi adalah aktivitas suatu senyawa yang dapat menghambat atau membunuh jamur tertentu, sehingga antifungi ini diharapkan dapat menyembuhkan suatu penyakit yang disebabkan oleh infeksi jamur. Pada umumnya obat antifungi berhubungan dengan biosintesis dan integritas ergosterol, sterol utama pada membran sel jamur. Kelompok lainnya mengganggu dinding sel jamur, sintesis DNA inti sel jamur dan aktivitas inti sel jamur. Berdasarkan mekanisme aksi antifungi, dapat dibagi menjadi lima kelompok agen, yaitu poliene,3azole, alilamin, ekinokandin dan agen lain termasuk griseofulvin danflusitosin. ${ }^{3}$

Salah satu tanaman tradisional yang diharapkan dapat digunakan untuk antifungi dermatofitosis adalah temu putih (Curcuma zedoaria). Tanaman herbal ini mengandung senyawa kimia seperti kurkuminoid, minyak atsiri, astringensia, flavonoid, sulfur, gum, resin, tepung, sedikit lemak. ${ }^{4}$ Selain itu Curcuma zedoaria mengandung alkaloid, phenol, saponin, glikosida, steroid, terpenoid, dan kandungan lain yang diduga dapat digunakan sebagai antimikroba, antifungal, antikanker, antialergi, antioksidan, dan analgesic. Berbagai bagian tanaman ini ditemukan sebagai antikanker, antifungal, antiamebik, antimikroba, analgetik, antialergi dll. ${ }^{5}$

Penelitian yang dilakukan oleh Carvalho et al (2010) menunjukkan bahwa ekstrak sederhana rimpang Curcuma zedoaria $0,1-0,2 \%$ yang diberikan secara intraperitoneal pada hewan percobaan tikus yang diinduksi oleh sel melanoma B16F10 murine meningkatkan jumlah limfosit pada hari ke 15 dan 30 setelah pemberian, jumlah neutrofil meningkat setelah 15 hari pemberian, dan pemberian ekstrak selama 15-60 hari meningkatkan jumlah sel darah merah dan leukosit. ${ }^{6}$ Sedangkan berdasarkan penelitian yang telah dilakukan oleh windono dkk (2002) ekstrak etanol dari temu putih menunjukkan efek antifungi, dengan senyawa aktifetil-pmetoksisinamat (EPMS). ${ }^{7}$

Berdasarkan uraian diatas, penulis ingin melakukan penelitian tentang efek antifungi dari tanaman temu putih (Curcuma zedoaria) terhadap pertumbuhan jamur dermatofit Trichophyton spp dari hasil isolat pasien dermatofitosis

\section{METODE PENELITIAN}

\section{Alat dan Bahan}

Alat-alat yang dipakai pada penelitian ini adalah autoklaf (SMIC 


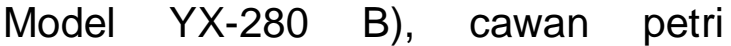
(Normax), chamber, gelas erlenmeyer (Iwaki Pyrex), gelas kimia 250 dan 500 $\mathrm{ml}$ (Iwaki Pyrex), inkubator (Memert), Laminar Air Flow (LAF), oven (Memert), timbangan analitik (Chyo), dan vial

Bahan-bahan yang digunakan adalah aquadest, cyclohexamide, chloramfenikol, larutan DMSO, etanol $70 \%$, ketokonazole, Larutan $\mathrm{NaCl}$, medium Sabaroud Dextrose Agar (SDA), medium Sabaroud Dextrose Broth (SDB), skuama pasien dermatofitosis Trichophyton mentagrophytes dan sampel temu putih (Curcuma zedoaria)

Prosedur Penelitian

Identifikasi

Trichophyton

\section{mentagrophytes}

Skuama pasien yang secara klinis didiagnosis dermatofitosis dan positif $\mathrm{KOH}$ ditanam pada media SDA yang mengandung $0,05 \mathrm{mg}$ cycloheximide dan $0,4 \mathrm{mg}$ chloramphenicol. Pertumbuhan jamur akan diamati setiap 3 hari setelah di inkubasi pada suhu $30^{\circ} \mathrm{C}$. Identifkasi spesies berdasarakan morfologi makroskopik dam mikroskopik koloni.

\section{Sterilisasi alat}

Sterilisasi alat dan bahan dengan cara membungkus alat-alat, kemudian alat-alat yang tahan terhadap pemanasan disterilkan pada Oven pada suhu $180^{\circ} \mathrm{C}$ selama 2 jam. Sedangkan alat yang tidak tahan terhadap pemanasan disterilkan pada autoklaf pada suhu $121^{\circ} \mathrm{C}$ dengan tekanan 15 atm selama 15 menit.

\section{Pengambilan dan penyiapan sampel}

Sampel yang diambil berasal dari tanaman sehat untuk menghindari adanya fitopatogen di dalam jaringan tanaman tersebut. Sampel dibersihkan dan dicuci dengan air mengalir, kemudian diangin-anginkan. Sampel yang telah kering kemudian diblender hingga menjadi serbuk

\section{Ekstraksi Sampel}

Sampel temu putih (Curcuma zedoaria) yang telah diserbuk ditimbang kemudian dimasukkan ke dalam bejana maserasi. Kemudian ditambahkan etanol $70 \%$ hingga merendam seluruh simplisia dan dibiarkan 2 sampai 3 hari dengan pengadukan beberapa kali. Ekstrak cair yang diperoleh dikeringkan dengan cara dirotavapor hingga diperoleh ekstrak etanol kental.

\section{Uji Aktivitas Antimikroba Metode} Dilusi

\section{Uji Kadar Hambat Minimim (KHM)}

Pengujian KHM dilakukan pada mikroba uji yang memberikan penghambatan pada uji skrining aktivitas antimikroba dari ekstrak 
etanol temu putih (Curcuma zedoaria), larutan tampak jernih setelah dengan membuat variasi konsentrasi diinkubasi dinyatakan sebagai harga sampel ekstrak. Sampel ditimbang sesuai dengan konsentrasi yang akan dibuat terhadap $1 \mathrm{ml}$ medium SDB dalam vial, dilarutkan dengan DMSO, ditambah $1 \mathrm{ml}$ SDB, dihomogenkan dan dimasukkan kedalam tabung reaksi steril, selanjutnya dimasukkan mikroba uji yang positif pada uji skrining antimikroba kedalam tiap tabung. Konsentrasi terendah dari ekstrak etanol temu putih (Curcuma zedoaria) dengan parameter dimana KHM.

\section{Uji Kadar Bunuh Minimum (KBM)}

Pengujian KBM dilakukan terhadap hasil inkubasi dari uji KHM, selanjutnya digoreskan pada media SDA, dan diinkubasi pada suhu $30^{\circ} \mathrm{C}$ selama 21 hari. Konsentrasi terendah dari ekstrak temu putih (Curcuma zedoaria) yang aktif sebagai antifungi dengan parameter berupa daerah tanpa pertumbuhan setelah diinkubasi dinyatakan sebagai harga KBM.

\section{HASIL PENELITIAN}

Tabel 1. Hasil Uji Konsentrasi Hambat Minimum (KHM) ekstrak etanol Temu Putih (Curcuma zedoaria) terhadap mikroba uji Trichophyton mentagrophytes.

\begin{tabular}{cc}
\hline Konsentrasi & Uji KHM \\
\hline $100 \%$ & Keruh \\
$75 \%$ & Keruh \\
$50 \%$ & Keruh \\
$25 \%$ & Keruh \\
$12,5 \%$ & Keruh \\
$\mathrm{K}(+)$ & Jernih \\
$\mathrm{K}(-)$ & Keruh \\
\hline
\end{tabular}


Tabel 2. Hasil Uji Konsentrasi bunuh Minimum Ekstrak Etanol Temu Putih (Curcuma zedoaria) terhadap mikroba uji Trichophyton mentagrophytes.

\begin{tabular}{cc}
\hline Konsentrasi & Uji KBM \\
\hline $100 \%$ & Tidak ada pertumbuhan \\
$75 \%$ & Tidak ada pertumbuhan \\
$50 \%$ & Tidak ada pertumbuhan \\
$25 \%$ & Ada pertumbuhan \\
$12,5 \%$ & Ada pertumbuhan \\
K (+) & Tidak ada pertumbuhan \\
K (-) & Ada pertumbuhan \\
K medium & Tidak ada pertumbuhan \\
\hline
\end{tabular}
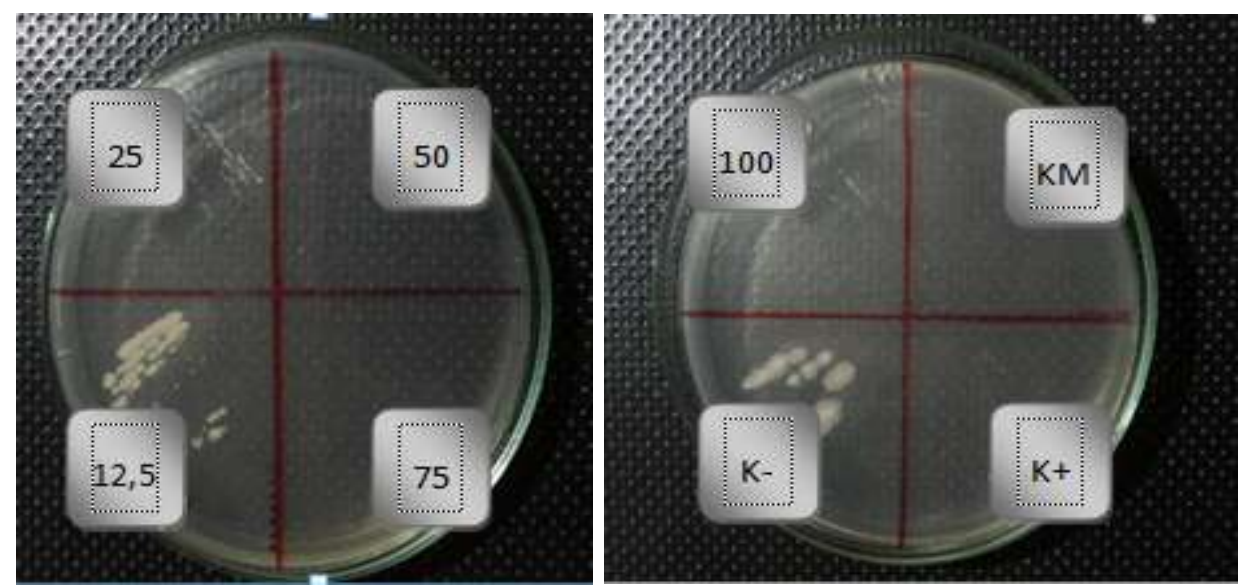

Gambar 1. Foto hasil pengujian Konsentrasi Bunuh Minimum (KBM) ekstrak etanol temu putih (Curcuma zedoaria) terhadap Mikroba Uji Trichophyton mentagrophytes

\section{PEMBAHASAN}

Antifungi merupakan salah satu antibiotika yang digunakan untuk menyembuhkan infeksi yang disebabkan oleh fungi atau jamur. Salah satu tanaman tradisional yang diharapkan dapat digunakan untuk antifungi dermatofitosis adalah temu putih (Curcuma zedoaria). Temu putih
(Curcuma zedoaria) mengandung senyawa kimia seperti kurkuminoid, minyak atsiri, astringensia, flavonoid, sulfur, gum, resin, tepung, sedikit lemak. ${ }^{4}$ Selain itu Curcuma zedoaria mengandung alkaloid, phenol, saponin, glikosida, steroid, terpenoid, dan kandungan lain yang diduga dapat digunakan sebagai antimikroba, 
antifungal, antikanker, antialergi, antioksidan, dan analgesic. Pengujian temu putih sebagai antijamur juga didasarkan pada penggunaan tradisional yaitu sebagai obat penyakit kulit seperti kurap atau kudis dan penyakit tinea.

Dalam penelitian ini untuk mendapatkan jamur Trichophyton mentagrophytes sebagai mikrpbs uji, digunakan sampel skuama positif $\mathrm{KOH}$ dari pasien dermatofitosis dengan menggunakan medium SDA yang mengandung cycloheximide.

Penggunaan Cyclohexamide bertujuan agar hanya jamur golongan jamur dermatofit yang dapat terdeteksi, sementara penggunaan Chloramphenicol bertujuan agar media tidak terkontaminasi oleh bakteri. Dari hasil kultur diperoleh hasil positif Trichophyton mentagrophytes dengan ciri-ciri memiliki koloni berwarna putih, bagian belakang berwarna kuning hingga kecoklatan. Makrokonidia pada medium SDA jarang terlihat, sedangkan mikrokonidianya banyak berada disepanjang hifa, sendiri atau bergerombol,hifa berbentuk spiral (Gambar 1).

Metode yang digunakan dalam pengujian aktivitas antijamur pada penelitian ini adalah dengan metode konsentrasi hambat minimum (KHM) dan konsentrasi bunuh minimim (KBM). Kelompok perlakuan yang digunakan pada penelitian ini adalah kelompok sampel temu putih yang berisi ekstrak temu putih, medium dan Trichophyton mentagrophytes dengan konsentrasi $12,5 \%, 25 \%, 50 \%, 75 \%$, $100 \%$, kelompok kontrol positif $(\mathrm{K}+)$ yang berisi medium, Trichophyton mentagrophytes, ketokonazole dan kontrol negatif ( $\mathrm{K}$-)yang berisi medium dan Trichophyton mentagrophytes.

Medium Saboroud Dekstrosa Agar (SDA) merupakan medium agar yang digunakan pada metode KBM dan untuk menumbuhkan biakan mikroba uji. Sedangkan medium Saboroud Dekstrosa Broth (SDB) merupakan medium cair yang digunakan pada pengujian Konsentrasi Hambat Minimum (KHM). Medium SDA dan SDB ini berisi dekstrosa sebagai sumber karbohidrat yang diketahui dapat menunjang pertumbuhan fungi.

Pengujian Konsentrasi Hambat Minimum (KHM). Dimana Konsentrasi Hambat Minimum (KHM) adalah konsentrasi minimal dari suatu zat yang akan menghambat pertumbuhan suatu mikroorganisme. Pada pengujian ini digunakan konsentrasi $12,5 \%$, 25\%, 50\%, $75 \%$ dan $100 \%$ antara sampel dan medium Saboroud 
Dekstrosa Broth (SDB). Dimana medium SDB ini merupakan medium cair yang digunakan pada pengujian Konsentrasi Hambat Minimum (KHM). Kegunaan dari Uji Konsentrasi Hambat Minimum (KHM) ini adalah untuk mengetahui konsentrasi terendah dari suatu sampel dalam menghambat pertumbuhan mikroba uji. Dimana semakin keruh larutan uji maka semakin kecil penghambatan terhadap mikroba uji yang terdapat pada larutan uji dan sebaliknya dimana semakin jernih larutan uji maka semakin besar penghambatan terhadap mikroba uji yang terdapat pada larutan uji.

Dari hasil pengujian Konsentrasi Hambat Minimum (KHM) tidak diperoleh nilai KHM dikarenakan warna sampel dan kekentalan sampel yang mengganggu dalam pengamatan. Sedangkan untuk kontrol positif ketokonazol menunjukkan warna yang jernih yang menunjukkan adanya penghambatan Trichophyton mentagrophytes oleh ketokonazol, dan kontrol negatif berwarna keruh yang menunjukkan masih adanya

\section{Trichophyton mentagrophytes}

Pengujian dilanjutkan dengan uji Konsentrasi Bunuh Minimum (KBM) yaitu konsentrasi minimal dari suatu zat yang membunuh (KBM) dimana pengujian ini dilakukan dengan menggoreskan masing-masing hasil inkubasi pada uji KHM pada medium Saboroud Dekstrosa Agar (SDA) dalam cawan petri dan diinkubasi kembali pada suhu $30{ }^{\circ} \mathrm{C}$ selama $21 \mathrm{x}$ 24 jam. Nilai Konsentrasi Bunuh Minimum (KBM) ditunjukkan dengan tidak adanya pertumbuhan fungi pada konsentrasi terendah sampel.

Berdasarkan hasil pengujian yang telah dilakukan maka, diperoleh nilai Konsentrasi Bunuh Minimum (KBM) untuk Trichophyton mentagrophytes terdapat pada konsentrasi 50\%. Mekanisme penghambatan pertumbuhan jamur oleh ekstrak etanol temu putih kemungkinan melalui perusakan permeabilitas membran sel. ${ }^{8}$ Untuk itu perlu penelitian lebih lanjut mengenai mekanisme penghambatan jamur dan efeknya terhadap hewan coba.

\section{KESIMPULAN}

Dari hasil penelitian ini dapat ditarik kesimpulan bahwa ekstrak etanol temu putih (Curcuma zedoaria) memiliki daya bunuh terhadap pertumbuhan koloni jamur Trichophyton mentagrophytes dengan nilai konsentrasi bunuh minimum (KBM) adalah $50 \%$.

\section{DAFTAR PUSTAKA}

1. Havlickova B, Czaika VA, Friedrich $M$. Epidemiological trends in skin 
mycoses worldwide. Mycoses 2008;51:2.

2. Verma S, Haffernan MP. Fizpatrick's Dermatology in General Medicine. Edisi VII. New York : Mc Graw Hills, 2008.

3. Chen SC, Sorrel TC. New drugs, Old drugs : Antifungal agents. MJA 2007:187:404-409.

4. Lobo R, Prabhua KS, Shirwaikara A, Shirwaikarb A. Curcuma zedoaria rosc. (white turmeric): a review of its chemical, pharmacological and ethnomedicinal properties. Journal of Pharmacy and Pharmacology 2009; 61: 13-21.

5. Sumathi $S$, Iswariya GT, Sivaprabha B, Dharani B, Radha P, Padma PR. Comparative study of radical scavenging activity and phytochemical analysis of fresh and dry rhizomes of Curcuma zedoaria. IJPSR. 2013; 4(3): 10691073.

6. Carvalho FR, Vassão RC, Nicoletti MA, Maria DA. Effect of Curcuma zedoaria crude extract against tumor progression and immunomodulation. J Venom Anim Toxins incl Trop Dis 2010; 16(2): 324-41.

7. Windono MS, Parfiani N. Curcuma Zedoaria Rosc. Kajian Pustaka Kandungan Kimia dan aktivitas Farmakologik, Artocaspus 2002, 2(1) : 1-10.

8. Himaja M, Ranjhita A, Ramana MV, Karigar

A. Phytochemical screening and antioxidant activity of rhizome part of Curcuma zedoaria. IJRAP 2010; 1(2): 414- 7 